\title{
Production of jacaranda plantlets by minicutting
}

\section{Produção de mudas de jacaranda por miniestaquia}

\section{Mariana Fauerharmel ${ }^{1}$; Dilson Antônio Bisognin ${ }^{2 *}$; Kelen Haygert Lencina ${ }^{3}$; Thaíse da Silva Tonetto ${ }^{4}$; Jonas Marcelo Meltzer ${ }^{5}$; Joane Helena Maggioni ${ }^{6}$}

\author{
Highlights: \\ Plantlets production of a species of great interest to forestry. \\ Jacaranda ministumps respond satisfactorily to clonal mini-garden management. \\ Rooting of minicuttings without use of rooting inductors. \\ Rooting of of minicuttings without the need for special propagation structures.
}

\begin{abstract}
The objective of this study was to investigate the production of jacaranda (Jacaranda mimosifolia D. Don) plantlets by minicutting. For this, a mini-clonal hedge was established to supply sprouts for minicuttings. For adventitious rooting, the minicuttings were treated with hydroalcoholic solution of indolebutyric acid at concentrations of 0,1000 , and $2000 \mathrm{mg} \mathrm{L}^{-1}$ and grown in a greenhouse. The survival of minicuttings was evaluated at 30,60 , and 90 days, and rooting, callus, sprouting, leaf area, root area, aerial dry mass, root dry mass, total dry mass, and aerial/root dry mass ratio were assessed at 90 days. The rooted minicuttings were treated with different volumes of nutrient solution $(0,25$, and $50 \mathrm{~mL}$ ) and were evaluated for survival, height, diameter, leaf area, root area, aerial dry mass, root dry mass, and aerial/root dry mass ratio of the plantlets after 30 days of cultivation in a shade house and full sunlight. Jacaranda can be established in a mini-clonal hedge for the production of shoots necessary for the preparation of minicuttings. The minicuttings are rooted in a greenhouse without use of indolebutyric acid. The plantlets produced can be acclimatized in a shade house and rustified in full sun. Jacaranda plantlets can be produced by minicuttings.
\end{abstract}

Key words: Indolebutyric acid. Jacaranda mimosifolia D. Don. Vegetative propagation.

\section{Resumo}

Este trabalho teve por objetivo estudar a produção de mudas de jacarandá (Jacaranda mimosifolia D. Don) por miniestaquia. Para isso, foi estabelecido um minijardim clonal para o fornecimento de brotações para a confecção de miniestacas. Para o enraizamento adventício, as miniestacas foram tratadas ou não com solução hidroalcoólica de ácido indolbutírico na concentração de 0,1000 e 2000

\footnotetext{
1 Discente do Curso de Doutorado do Programa de Pós-Graduação em Engenharia Floresta, Universidade Federal de Santa Maria, UFSM, Santa Maria, RS, Brasil. E-mail: marifauer@gmail.com

2 Prof. Dr., Departamento de Fitotecnia, UFSM, Santa Maria, RS, Brasil. E-mail: dbisognin@gmail.com; dilson.bisognin@ufsm.br

3 Prof $^{\text {a }}$ Dr $^{\mathrm{a}}$, Departamento de Agricultura, Biodiversidade e Florestas, Universidade Federal de Santa Catarina, UFSC, Curitibanos, SC, Brasil. E-mail: khaygert@gmail.com; kelen.lencina@ufsc.br

4 Pós-Doutoranda do Programa de Pós-Graduação em Engenharia Floresta, UFSM, Santa Maria, RS, Brasil. E-mail: thaisetonetto@ hotmail.com

5 Eng ${ }^{\circ}$ Florestal, Santa Maria, RS, Brasil. E-mail: jonasmeltzer@gmail.com

6 Discente do Curso de Doutorado do Programa de Pós-Graduação em Genética e Melhoramento, Universidade Federal de Viçosa, UFV, Viçosa, MG, Brasil. E-mail: joane.mgg@hotmail.com

* Author for correspondence
} 
mg L ${ }^{-1}$ e cultivadas em casa de vegetação climatizada. A sobrevivência das miniestacas foi avaliada aos 30, 60 e 90 dias e o enraizamento, calos, brotação, área foliar, área de raiz, massa seca aérea, massa seca de raízes, massa seca total e massa seca aérea/raiz aos 90 dias. As miniestacas enraizadas foram tratadas com diferentes volumes de solução nutritiva $(0,25$ e $50 \mathrm{~mL})$ e avaliadas quanto à sobrevivência, altura, diâmetro, área foliar, área radicular, massa seca aérea, massa seca radicular e relação massa seca aérea/radicular das plantas após 30 dias de cultivo em casa de sombra e pleno sol. O jacarandá pode ser estabelecido em minijardim clonal para a produção de brotações necessárias para o preparo de miniestacas. As miniestacas enraízam em casa de vegetação e sem a necessidade de ácido indolbutírico. As mudas produzidas podem ser aclimatizadas em casa de sombra e rustificadas em pleno sol. Mudas de jacarandá podem ser produzidas por miniestaquia.

Palavras-chave: Ácido indolbutírico. Jacaranda mimosifolia D. Don. Propagação vegetativa.

\section{Introduction}

Jacaranda mimosifolia D. Don (Bignoniaceae), commonly known as jacaranda-mimoso or jacaranda, is a tree species native to Argentina, Bolivia and Paraguay, which can be found in temperate and tropical regions (Lorenzi, Souza, \& Torres, 2003). This tree species is mainly used in the landscaping of parks and large gardens, given the beauty of its flowers. It is also used in urban planting, woodworking and as a medicinal plant.

The propagation of jacaranda is usually achieved from seeds, which results in rapid plant growth. However, the seeds present low longevity, which reduces the storage potential and, consequently, the possibility of obtaining seedlings of high quality and in adequate quantity. Furthermore, seasonality should be considered in seed production, as it results in limitation of seed availability in years of absent or lower fruiting (Tonetto, Araujo, Muniz, Walker, \& Berghetti, 2015). This seedling production problem can be addressed by vegetative propagation. For example, jacaranda can be propagated by tissue culture (Maruyama, Ishii, Saito, \& Ohba, 1993) and cuttings (Miyajima et al., 2004). However, there are no reports regarding the use of minicuttings for the production of clonal plantlets of this species.

The minicutting is a variation of the technique of cutting and presents advantages for the production of plantlets of woody species such as improving rooting and root system structure (Xavier, Wendling, \& Silva, 2013). It can also reduce or eliminate the use of plant growth regulators. In addition, it requires less physical space for the production of propagules in mini-clonal hedge and shorter period of time for rooting of minicuttings and for acclimatization of plantlets (Ferriani, Ribas-Zuffellato, \& Wendling, 2010), facilitating the propagation of selected individuals (Xavier et al., 2013).

The adventitious rooting process of the minicuttings depends on several factors, such as the application of indolebutyric acid (IBA). IBA is highly effective in stimulating rooting, which is due to its lower photosensitivity and improved chemical stability in the plant, as it is less affected by the indoleacetic acid oxidase system (Hartmann, Kester, Davies, \& Geneve, 2011). For the growth of the plantlets, nutrition is one of the essential factors and each mineral element has a certain function linked to plant metabolism. Thus, periodic fertilization is usually necessary to achieve quality plantlet production in a short time (Wendling, Dutra, \& Grossi, 2006).

The aimed of this study was to evaluate the establishment of jacarandá plants in clonal minigarden, the effect of indolbutyric acid on the rooting of minicuttings, as well as the acclimatization and rustification of plantlets produced by minicuttings.

\section{Material and Methods}

The experiments were conducted at the Center for Plant Breeding and Propagation (MPVP), Plant 
Science Department of the Federal University of Santa Maria (UFSM), from June 2015 to February 2017.

The jacaranda mini-clonal hedge was established in October 2015, with a total of 48 seedlings that were 120 days old after sowing (Figure 1A). The plantlets were planted in four polyethylene trays (55 cm x $34 \mathrm{~cm} \times 15 \mathrm{~cm}$ ) with spacing of $10 \mathrm{~cm} \mathrm{x}$ $10 \mathrm{~cm}$ and the mini-clonal hedge was established according to the methodology used for other forest species in the MPVP-UFSM, such as Cabralea canjerana (Vellozo) Martius (Burin, Bisognin, Lencina, \& Gimenes, 2018a; Burin, Bisognin, Lencina, Somavilla, \& Pedroso, 2018b; Gimenes et al., 2015), Ilex paraguariensis A. St.-Hil. (Pimentel, Lencina, Pedroso, Somavilla, \& Bisognin, 2017) and Handroanthus heptaphyllus Vell. Mattos (Rodrigues, Pimentel, Lencina, Kielse, \& Bisognin, 2017). In the flood fertigation system, the nutrient solution was supplied for 15 min twice a day, with the aid of a digital programmer and a low flow submersible pump, drained by two holes arranged in the front of the tray. The nutrient solution was adapted from the study by Hoagland and Arnon (1950). The $\mathrm{pH}$ of the nutrient solution was maintained between 5.5 and 6.0 and the electrical conductivity was $1.5 \mathrm{~d} \mathrm{~S} \mathrm{~m}^{-1}$.

The plantlets were pruned at day 30 after planting in the soilless cultivation system at three heights, based on the number of remaining buds in the ministumps (i.e. 2, 4, or 6 buds), considering their opposite phyllotaxis. The ministumps were evaluated at day 30, 60, and 90 for survival percentage and sprout production. After this period, the ministumps underwent consecutive formation pruning during 9 months.

\section{Rooting of minicuttings}

The sprouts that developed from the ministumps were sectioned in double bud (opposite phyllotaxis) with $1.5-2.0 \mathrm{~cm}$ in length and a pair of leaves each with four pairs of leaflets. The minicuttings were treated with IBA hydroalcoholic solution at concentrations of 0,1000 , and $2000 \mathrm{mg} \mathrm{L}^{-1}$ for $10 \mathrm{~s}$. To prepare the solution, IBA was dissolved in 50\% ethyl alcohol (96 GL) and diluted in 50\% distilled water. The minicuttings were grown in $110 \mathrm{~cm}^{3}$ polyethylene tubes containing a commercial substrate mixture based on pinus bark and vermiculite in the proportion of 2:1 (v/v), as defined in preliminary tests. Rooting was carried out in a greenhouse with a relative humidity of approximately $65 \%$ and an average temperature of $27{ }^{\circ} \mathrm{C}$. The minicuttings received manual daily watering with watering aid. The percentage of survival was evaluated at day 30 , 60 , and 90 , while the percentage of rooting, callus formation, and sprouting were assessed after 90 days. The experiment was arranged in a randomized design, with 10 replicates of six cuttings.

After 90 days of culture in a greenhouse, the dry mass of the aerial part and roots and the root and leaf area were evaluated in eight rooted minicuttings. For these evaluations, the plantlets were sectioned into aerial parts and roots, which were weighed on a precision balance and placed in paper bags for drying in a forced air circulation oven at $70{ }^{\circ} \mathrm{C}$ until constant weight. The obtained dry weights of the aerial parts and of roots were used to determine the aerial/root dry mass ratio and total dry mass. The area of the root system and the leaf area were determined from images obtained using the scanner CanoScanLide 220, and measurements were made with the aid of the Winfolia software for the leaves and Image $\mathrm{J}$ for the roots. This experiment was also arranged in a randomized design, with eight repetitions of one plant.

\section{Plantlet growth}

After 120 days of cultivation in a greenhouse, the plantlets from the previous experiment were transferred to the shade house with a monofilament screen and 50\% shading, where they remained for 30 days for acclimatization. Thereafter, the plantlets were exposed to full sunlight for a further 30-day period for rustication. During these periods, the 
plantlets were randomized and received different volumes of nutrient solutions used in the miniclonal hedge, in the amounts of 0,25 , and $50 \mathrm{~mL}$ per tube per week. This form of cover fertilization is justified by the fact that the closed system of soilless cultivation used in this research (Bisognin, Bandinelli, Kielse, \& Fischer, 2015) presents a remnant of nutrient solution that can be used for the fertilization of the plantlets, at a given quantity and application frequency, such as every seven days.

The plantlets were evaluated before the beginning of acclimatization after 30 days of shade cultivation followed by 30 days of cultivation in full sun for survival percentage, height, and stem diameter. The height was measured with a millimeter ruler, from the stem of the plantlet to the insertion of the last pair of leaves. The diameter of stem was measured at the insertion of the plantlet with the substrate, with the aid of a digital caliper. The experiment was arranged in a completely randomized design, with 10 replicates of three plantlets.

At the end of the rustication period, five randomly selected plantlets were evaluated for aerial dry mass, root dry mass, and aerial/dry mass ratio as described above. In addition, growth increments in height and diameter of the stem were calculated during the growing season under the shade and full sun. The experimental design was a completely randomized design with five replications of one plantlet.

\section{Statistical analysis}

The data were subjected to test of normality of variances by the Shapiro-Wilk test and to meet normality assumptions, percentage data were transformed to arcosene $\sqrt{ } \mathrm{x} / 100$ and number data to $\sqrt{ } x+0.5$. Later the data were submitted to analysis of variance (ANOVA) by the F test. The treatments with significant differences were compared by using the Tukey test, at 5\% probability of error. The analyses were performed with the aid of the statistical software R-Studio version 1.0.143 (R Core Team, 2017).

\section{Results and Discussion}

Jacaranda plantlets presented adequate establishment in the system of cultivation without soil used for other forest species. After the establishment, the plantlets were subjected to different pruning heights based on the number of remaining buds $(2,4$, and 6 buds). In this experiment, the different pruning heights did not affect the survival of the ministumps or the production of shoots after 30, 60, and 90 days (data not shown). In all experiments, the ministumps developed new shoots, which indicates that jacaranda ministumps can be pruned to different heights, even with only a pair of buds left on the ministump. A similar result was observed for Azadirachta indica A. Juss, where the ministumps survived up to 189 days after the establishment of the minigarden regardless to the pruning height $(10,25$, or $40 \mathrm{~cm})$ (Fernandes et al., 2017).

The formation of the ministumps depends on the removal of the apex or pruning of the aerial part to break apical dominance and to induce the growth of adventitious buds that result in the production of lateral shoots used for the preparation of the minicuttings (Fernandes et al., 2017). In this study, different pruning heights of the aerial part were evaluated for the formation of the ministump. This is because the height of pruning varies with the species, the management conditions of the mini-clonal hedge (Fernandes et al., 2017), the phyllotaxis and the growth pattern to the internode. Therefore, the knowledge of the pruning height and the formation of the ministump in each species is important to maximize the production of shoots (in this study, the number of minicuttings produced was 501 , in an area of $7.48 \mathrm{~m}^{2}$ of mini-clonal hedge, which enabled the yield of 66.98 minicuttings $\mathrm{m}^{-2}$ ) and for the maintenance of an adequate size of the shoots, in order to obtain greater production of minicuttings and, consequently, plantlets. This is due to the increase in mortality rate after a very drastic pruning or the reduction of the life of the ministump in the case of less intense pruning. This 
is due to the excessive increase of height as a result of formation of new buds for induction of lateral shoots.

These results show that the establishment of mini-clonal hedge in a closed soilless hydroponic system and the management of ministumps were suitable for jacaranda asexual propagation, and thus could be used to produce sprouts for the preparation of minicuttings. All the ministumps survived during the 9 months of periodic pruning, indicating that jacaranda species is tolerant to injury caused during the collection of shoots, which is fundamental to enable the production of plantlets by minicutting. Furthermore, the ministumps presented adequate growth, considering the composition and management of the nutrient solution. This helped to collect shoots and to prepare minicuttings sufficient to conduct pilot tests needed to define the treatments for use in the rooting of cuttings (Figure 1B) and plantlet production (Figure 1C).
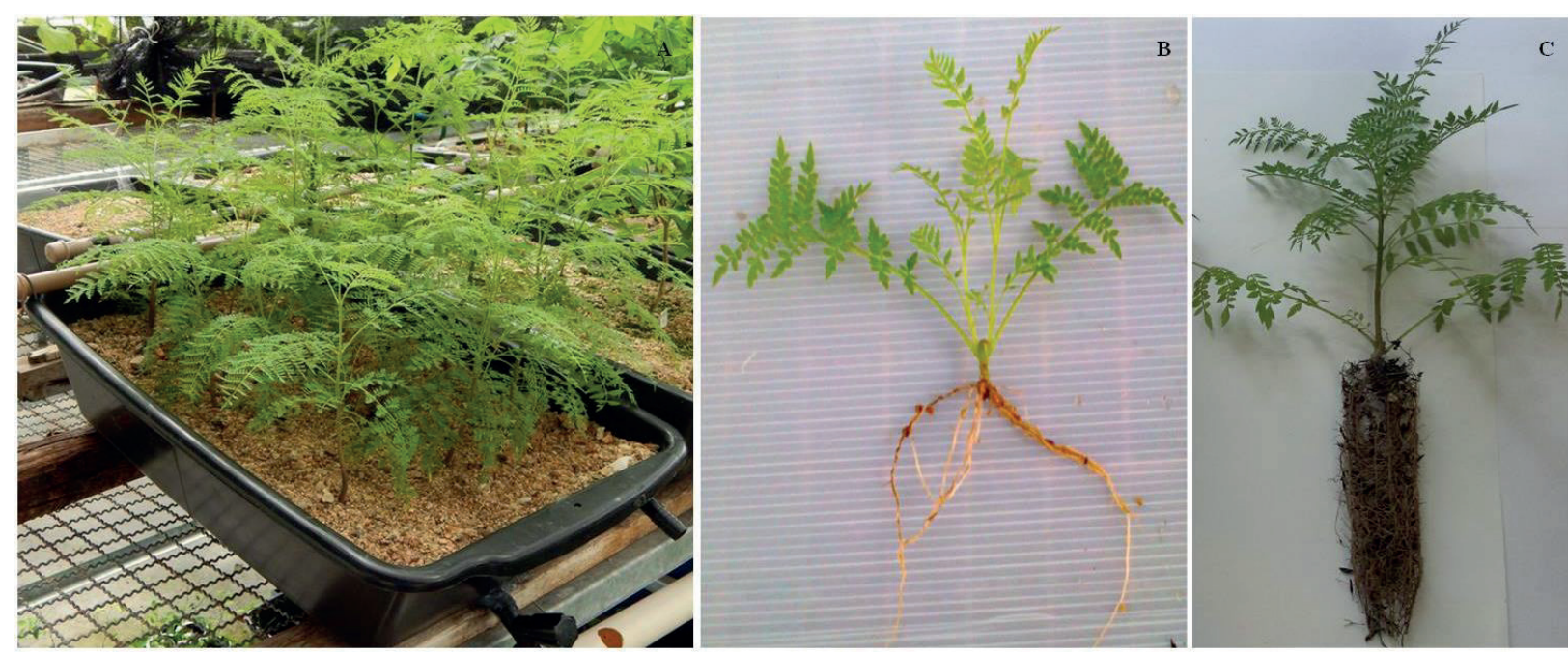

Figure 1. Jacaranda mini-clonal hedge established in a soilless cultivation system (A), minicutting rooted in a greenhouse (B), and rustified plantlet (C).

\section{Rooting of minicuttings}

No significant differences in percentages of survival, rooting, callus formation and sprouting were observed between the doses of IBA up to 90 days of cultivation of jacaranda minicuttings in a greenhouse (Table 1). The mean survival percentage was $79.4 \%$ and rooting percentage was $68.9 \%$ at day 90 . The percentage of sprouted minicuttings was also high, with an average of $76.1 \%$. With the exception of the percentage of minicuttings that formed callus, the coefficient of variation for all parameters was low, which indicates good reliability of the obtained results.

Treatment with IBA also did not affect the leaf and root area and dry mass production of aerial parts and roots, total dry mass, and the ratio of the dry mass of aerial parts to roots (Table 2). For these traits, the IBA treatment did not alter the observed values. Root dry mass showed the highest coefficient of variation, while for the other traits the coefficient of variation was below $50 \%$. 


\section{Table 1.}

Percentage of survival after 30, 60, and 90 days and percentage of rooting, callus formation, and sprouting after 90 days of cultivation of minicuttings of jacaranda treated with different doses of indolebutyric acid (IBA) in a greenhouse

\begin{tabular}{|c|c|c|c|c|c|c|}
\hline \multirow{2}{*}{$\frac{\text { AIB }}{\left(\mathrm{mg} \mathrm{L}^{-1}\right)}$} & \multicolumn{3}{|c|}{ Survival } & \multirow{2}{*}{$\begin{array}{c}\text { Rooting } \\
(\%)\end{array}$} & \multirow{2}{*}{$\begin{array}{c}\text { Callus } \\
(\%)\end{array}$} & \multirow{2}{*}{$\begin{array}{c}\text { Sprouting } \\
(\%)\end{array}$} \\
\hline & 30 days & 60 days & 90 days & & & \\
\hline 0 & 91.7 ns* & $83.3^{\mathrm{ns}}$ & $73.3^{\mathrm{ns}}$ & $65.0^{\mathrm{ns}}$ & $6.7^{\mathrm{ns}}$ & $81.7^{\mathrm{ns}}$ \\
\hline 1000 & 90.0 & 86.6 & 81.6 & 65.0 & 3.3 & 73.3 \\
\hline 2000 & 93.3 & 88.3 & 83.3 & 76.6 & 1.7 & 73.3 \\
\hline Average & 91.7 & 86.1 & 79.4 & 68.9 & 3.9 & 76.1 \\
\hline CV (\%) & 12.7 & 15.7 & 21.8 & 28.0 & 216.6 & 23.0 \\
\hline
\end{tabular}

*Not significant (ns) by Tukey test at $5 \%$ error of probability. CV $=$ Coefficient of variation.

Table 2

Root and leaf area $\left(\mathrm{cm}^{2}\right)$, dry mass ( $\mathrm{mg}$ ) of aerial parts and roots, total dry mass (mg), and the ratio of dry mass of aerial parts to roots of jacaranda minicuttings treated with different doses of indolebutyric acid (IBA) after 90 days of cultivation in a greenhouse

\begin{tabular}{ccccccc}
\hline $\begin{array}{c}\text { IBA } \\
\left(\mathrm{mg} \mathrm{L}^{-1}\right)\end{array}$ & Root area & Leaf area & $\begin{array}{c}\text { Aerial dry } \\
\text { mass }\end{array}$ & Root dry mass & Total dry mass & $\begin{array}{c}\text { Aerial/Root } \\
\text { dry mass ratio }\end{array}$ \\
\hline 0 & $9374.2^{\text {ns* }}$ & $3863.4^{\text {ns }}$ & $200.0^{\text {ns }}$ & $70.0^{\text {ns }}$ & $270.0^{\text {ns }}$ & $2.9^{\text {ns }}$ \\
1000 & 9370.4 & 4320.0 & 230.0 & 70.0 & 300.0 & 3.3 \\
2000 & 9107.9 & 4388.1 & 240.0 & 80.0 & 320.0 & 3.0 \\
Average & 9284.2 & 4190.5 & 220.0 & 70.0 & 290.0 & 3.1 \\
CV $(\%)$ & 32.7 & 46.9 & 46.9 & 63.4 & 49.6 & 45.7 \\
\hline
\end{tabular}

*Not significant (ns) by Tukey test at $5 \%$ error of probability. CV $=$ Coefficient of variation.

In this study, high percentages of survival, rooting, and sprouting were observed in jacaranda minicuttings after 90 days of cultivation under greenhouse conditions. In addition, the rooted minicuttings presented adequate leaf and root area, which was consistent with the ratio of the dry mass of aerial parts to that of roots. Interestingly, the minicuttings of jacaranda rooted under benches in a greenhouse, without the control of relative humidity, which greatly facilitates the production of plantlets from minicuttings. The minicuttings of some species, especially tree species, need to be maintained in a high humidity environment for adventitious rooting, which can only be achieved within specialized environments, such as in a moist chamber. However, these conditions require greater investments in vegetative propagation structures and often constitute a major impediment to the production of plantlets using minicuttings. In addition, environments with high relative air humidity, especially when associated with high temperatures, may favor disease incidence, especially in a greenhouse (Alfenas, Zauza, Mafia, \& Assis, 2009) and thus cause the mortality of minicuttings, reducing the number of plantlets produced.

The percentages of survival, rooting, and sprouting were high for all treatments, indicating that jacaranda minicuttings do not require IBA for adventitious rooting. The high percentages of survival indicate that the reserves were sufficient to keep minicuttings alive during the adventitious 
rooting process. This is due to the fact that death of the minicuttings is often associated with the depletion of accumulated reserves in the tissues, and their higher survival is related to the production of carbohydrates and the complexes responsible for rooting (Bordin, Hidalgo, Bürkle, \& Roberto, 2005; Silva, Reges, Melo, Santos, \& Sousa, 2015).

The observed high rooting percentages without the need for IBA are in agreement with Miyajima et al. (2004) who studied the rooting of herbaceous jacaranda cuttings. This demonstrates that jacaranda does not require IBA for adventitious rooting, likely due to the sufficient endogenous auxin content and optimal hormonal balance between auxins and cytokinins (Hartmann et al., 2011). In separate studies, other species did not require the application of IBA for adventitious rooting in Handroanthus heptaphyllus (Oliveira, Barroso, Lâmonica, \& Carvalho, 2016; Rodrigues et al., 2017), Calophyllum brasiliense Cambess. (Silva, Oliveira, Monte, \& Xavier, 2010), and Anadenanthera macrocarpa (Benth) Benan (Dias, Xavier, Oliveira, Paiva, \& Correia, 2012).

In woody species, the root primordia may be the origin of cells close to the vascular system of callus tissue (Hartmann et al., 2011). Thus, the formation of callus at the base of the minicuttings may be essential for the rooting process, since this capacity is indicative of the processing efficiency and tissue differentiation (Penso, Sachet, Maro, Patto, \& Citadin, 2016). However, the high percentage of rooting and low percentage of callus demonstrate that there was no relationship between these parameters.

Another relevant aspect observed in the present study is that the use of IBA and dose increase did not increase callus formation in minicuttings. This result was not expected, considering that IBA plays a role in the cell development pathway, in which differentiated stem cells become dedifferentiated into callus cells (Hartmann et al., 2011). This fact is in line with the finding of Zottele and Aoyama
(2014) who verified that the primordia of Justicia wasshauseniana Profice roots originated directly from the basal region of the cuttings, independent from the node and callus formation.

The satisfactory responses obtained for adventitious rooting may have been positively influenced by the high sprouting percentage. The presence of leaves and the formation of new shoots are responsible for the production of photoassimilates and for the increase of the reserves, which favors rooting (Paiva \& Gomes, 2011). The formation of shoots from the cuttings also indicates the appropriate allocation of reserves, and results in plantlets with adequate balance between aerial parts and root system. The results of leaf and root area and production and partitioning of assimilates to different organs clearly show that after 90 days of cultivation in the greenhouse, the jacaranda plantlets presented high quality. This is supported by the average of the ratio of aerial dry mass to root dry mass of 3.63. This relationship is an important indicator for the quality of plantlets, with a value higher than 2.0 (Gomes \& Paiva, 2011) considered adequate for evaluation of jacaranda plantlets.

\section{Plantlet growth}

There were no significant differences in plantlet survival percentage and the increase in stem diameter during cultivation in a shade house and full sun between the volumes of nutrient solution applied (Table 3). The survival percentage improved under the both environments, suggesting that the management practices adopted were appropriate for jacaranda plantlets. For the increase in stem diameter, a high coefficient of variation was observed, which makes it difficult to detect significant differences between treatments. The application of nutrient solution increased the height of plantlets under both environments (Table 3). These differences in height of the plantlets with the weekly application of nutrient solution during acclimatization in a shade house and the rustication 
in full sun were in agreement with the increase in leaf area and total dry mass (Table 4).

In these experiments, the survival of the plantlets in the shade house and in full sun was high (above $92 \%$ ), indicating adaptation to the cultivation conditions and the management practices adopted.
A similar result was observed in a study using rooted minicuttings of Peltophorum dubium (Spreg) Taub. wherein satisfactory plantlet survival was observed during the hardening process in a greenhouse $(100 \%)$ and full sun (100\%) (Mantovani, Roveda, Tres, Fortes, \& Grando, 2017).

Table 3

Survival percentage $(\%)$, initial height $(\mathrm{cm})$, increase in height $\left(\mathrm{cm}^{-1}\right)$, initial stem diameter $(\mathrm{mm})$, and increase in stem diameter $\left(\mathrm{mm}^{-1}\right)$ of treated jacaranda plantlets with different volumes of nutrient solution during 30 days under a shade house (SH) and full sun (FS) cultivation

\begin{tabular}{|c|c|c|c|c|c|c|c|c|}
\hline \multirow{2}{*}{$\begin{array}{l}\text { Nutrient solution } \\
\quad(\mathrm{mL})\end{array}$} & \multicolumn{2}{|c|}{ Survival } & \multirow{2}{*}{$\begin{array}{l}\text { Initial } \\
\text { height }\end{array}$} & \multicolumn{2}{|c|}{ Increase in height } & \multirow{2}{*}{$\begin{array}{l}\text { Initial stem } \\
\text { diameter }\end{array}$} & \multicolumn{2}{|c|}{ Increase in stem diameter } \\
\hline & $\mathrm{SH}$ & FS & & $\mathrm{SH}$ & FS & & DS & FS \\
\hline 0 & 91.4 ns* & $87.9^{\mathrm{ns}}$ & 5.2 & $2.8 \mathrm{~b}^{*}$ & $1.5 \mathrm{~b}$ & 3.6 & $0.7^{\mathrm{ns}}$ & $0.4^{\mathrm{ns}}$ \\
\hline 25 & 97.4 & 97.4 & 5.6 & $5.9 \mathrm{a}$ & $2.9 \mathrm{a}$ & 3.7 & 1.2 & 0.6 \\
\hline 50 & 91.2 & 91.2 & 4.7 & $5.4 \mathrm{a}$ & $2.6 \mathrm{a}$ & 3.5 & 1.1 & 0.2 \\
\hline Average & 93.3 & 92.2 & 5.2 & 4.7 & 2.3 & 3.6 & 1.0 & 0.4 \\
\hline CV $(\%)$ & 27.1 & 26.7 & - & 44.5 & 68.6 & - & 121.1 & 165.0 \\
\hline
\end{tabular}

"Not significant (ns) and values followed by different letter do differ by Tukey test at $5 \%$ error of probability. CV $=$ coefficient of variation.

\section{Table 4}

Root and leaf area $\left(\mathrm{cm}^{2}\right)$, dry mass $(\mathrm{mg})$ of aerial parts and roots, total dry mass (mg), and the ratio of the dry mass of aerial parts to that of roots of jacaranda plantlets subjected to different volumes of nutrient solution during 30 days of cultivation in a shade house and in full sun

\begin{tabular}{|c|c|c|c|c|c|c|}
\hline \multirow{2}{*}{$\begin{array}{l}\text { Nutrient solution } \\
\qquad(\mathrm{mL})\end{array}$} & \multirow{2}{*}{ Root area } & \multirow{2}{*}{ Leaf area } & \multicolumn{4}{|c|}{ Dry mass (mg) } \\
\hline & & & Aerial & Root & Total & Aerial/Root \\
\hline & \multicolumn{6}{|c|}{ Shade house } \\
\hline 0 & 27506.8 ns* & $3320.3 \mathrm{~b}$ & $352.0^{\text {ns }}$ & $463.0^{\text {ns }}$ & $815.0 \mathrm{~b}$ & $0.76^{\mathrm{ns}}$ \\
\hline 25 & 32158.8 & $8179.0 \mathrm{a}$ & 656.0 & 899.0 & $1556.0 \mathrm{ab}$ & 0.72 \\
\hline 50 & 26188.8 & $10306.5 \mathrm{a}$ & 698.0 & 987.0 & $1685.0 \mathrm{a}$ & 0.70 \\
\hline Average & 28618.1 & 7278.6 & 568.0 & 783.0 & 1352.0 & 0.72 \\
\hline \multirow[t]{2}{*}{ CV (\%) } & 37.9 & 26.2 & 35.3 & 43.4 & 31.6 & 45.4 \\
\hline & \multicolumn{6}{|c|}{ Full sun } \\
\hline 0 & $44672.5^{\mathrm{ns}}$ & $2863.8^{\text {ns }}$ & $404.0^{\text {ns }}$ & $501.0^{\mathrm{ns}}$ & $1601.0^{\mathrm{ns}}$ & $0.81^{\mathrm{ns}}$ \\
\hline 25 & 57998.3 & 6864.0 & 765.0 & 484.0 & 2123.0 & 1.58 \\
\hline 50 & 48338.5 & 4508.8 & 514.0 & 404.0 & 1690.0 & 1.27 \\
\hline Average & 50336.4 & 4745.5 & 561.0 & 463.0 & 1805.0 & 1.22 \\
\hline CV (\%) & 46.3 & 47.1 & 41.4 & 38.9 & 35.7 & 61.4 \\
\hline
\end{tabular}

"Not significant (ns) and values followed by different letter do differ by Tukey test at $5 \%$ error of probability. CV $=$ coefficient of variation. 
It is also possible that the container (110 $\mathrm{cm}^{3}$ ) restricted the growth of the root system and limited the utilization and absorption of nutrients from a larger volume of the added nutrient solution. The use of containers with larger volume promoted the development of plantlets of Mimosa caesalpiniifolia Benth. (Melo, Abreu, Leles, Oliveira, \& Silva, 2018), while containers with smaller volume restricted the accumulation of nutrients in Mezilaurus itauba Taub. ex Mez and Platymiscium ulei Harms (Ferreira, Santos, Tucci, $\&$ Costa, 2017). This shows the influence of the volume of the container on the growth of plantlets of forest species, which will be investigated in the next experiments.

The fact that there is no difference between the characters evaluated for the different volumes of nutrient solution tested under the full sun environment probably indicates a restriction to the acclimatization process, with greater light exposure. When plants that are adapted to the shade are transferred to full light, the leaves tend to undergo photoinhibition and foliar bleaching, and may even senesce (Taiz \& Zeiger, 2013). In addition, typical foliar symptoms, such as chlorosis, can sometimes be the result of an environmental response not related to nutritional stress, but rather to damage caused by increasing the temperature in full sun or the reduction of water and nutrient absorption capacities by the roots (Jacobs \& Landis, 2009).

The observed values of increases in plantlet height, leaf area, and total dry mass demonstrate that the species invests the largest allocation of biomass in the aerial parts. Jacaranda plantlets showed stem diameter within the ranges reported in the literature. However, the height was below the referred value, which may be due to specific characteristics of the species. According to Xavier et al. (2013), a plantlet produced by the genus Eucalyptus minicutting must have height ranging between $20 \mathrm{~cm}$ and $40 \mathrm{~cm}$ and stem diameter above $2.0 \mathrm{~mm}$. If these values are used as the reference, the jacaranda plantlets must be maintained in a shade house for a longer period of time and in full sun before being sold or planted in the field.

These results show that jacaranda plantlets can be used for the establishment of mini-clonal hedge in a closed soilless cultivation system. Jacaranda plantlets adapt to the pruning of the ministumps and successive collection of shoots necessary for the preparation of minicuttings for adventitious rooting. The rooting of cuttings can be done in a greenhouse without need for specific structures and the application of IBA, which facilitates the process and reduces costs of jacaranda production using minicutting. Rooted minicuttings can be acclimatized in a shade house and rustified in full sun, when the proportion of $25 \mathrm{~mL}$ of nutrient solution per tube can be applied weekly. The excess nutrient solution should be considered as a residue that cannot be directly discarded in the environment, and its use for cover fertilization eliminates waste and provides a suitable source of the nutrients for production of jacaranda plantlets. In addition, cover fertilization with residual nutrient solution enhances plantlet height, leaf area, and total dry mass, which increases the ability of the plantlets to take advantage of solar energy to produce photoassimilates and complete the growth before planting in the field.

\section{Conclusions}

Jacaranda can be established in a mini clonal hedge for the production of shoots necessary for the preparation of minicuttings. The minicuttings are rooted in a greenhouse without use of indolebutyric acid. Rooted minicuttings can be acclimatized in a shade house and rustified in full sun, enabling the production of jacaranda plantlets from minicuttings.

\section{Referências}

Alfenas, A. C., Zauza, A. A. V., Mafia, R. G., \& Assis, T. F. (2009). Clonagem e doenças do eucalipto (2a ed.). Viçosa: Universidade Federal de Viçosa. 
Bisognin, D. A., Bandinelli, M. G., Kielse, P., \& Fischer, H. (2015). Rooting potential of minicuttings for the production of potato plantlets. American Journal of Plant Sciences, 6(2), 366-371. doi: 10.4236/ajps. 2015.62042

Bordin, I., Hidalgo, P. C., Bürkle, R., \& Roberto, S. R. (2005). Efeito da presença da folha no enraizamento de estacas semilenhosas de porta-enxertos de videira. Ciência Rural, 35(1), 215-218. doi: 10.1590/ S010384782005000100035

Burin, C., Bisognin, D. A., Lencina, K. H., \& Gimenes, E. S. (2018a). Early selection of Cabralea canjerana for propagation by mini-cutting. Pesquisa Agropecuária Brasileira, 53(9), 1018-1024. doi: 10.1590/ s0100204x2018000900005

Burin, C., Bisognin, D. A., Lencina, K. H., Somavilla, T. M., \& Pedroso, M. F. (2018b). Enraizamento de miniestacas em diferentes épocas de coleta para a seleção de clones de canjerana. Revista Brasileira de Ciências Agrárias, 13(2), 5530. doi: 10.5039/ agraria.v13i2a5530

Dias, P. C., Xavier, A., Oliveira, L. S., Paiva, H. N., \& Correia, A. C. G. (2012). Propagação vegetativa de progênies de meios-irmãos de angico-vermelho (Anadenanthera macrocarpa (Benth) Brenan) por miniestaquia. Revista Árvore, 36(3), 389-399. doi: 10.1590/S0100-67622012000300001

Fernandes, S. P. S., Arriel, E. F., Almeida, E. P., Araujo, A. N., Arriel, D. A. A., \& Justino, S. T. P. (2017). Altura de decepa para estabelecimento de minijardim clonal de nim (Azadirachta indica A. Juss). Agropecuária Cientifica no Semiárido, 13(1), 67-71. doi: 10.30969/ acsa.v13i1.780

Ferreira, M. S., Santos, J. Z. L., Tucci, C. A. F., \& Costa, L. V. (2017). Crescimento inicial de itaúba e macacaúba em recipientes de diferentes tamanhos. Ciência Florestal, 27(2), 499-508. doi: 10.5902/ 1980509827731

Ferriani, A. P., Ribas-Zuffellato, K. C., \& Wendling, I. (2010). Miniestaquia aplicada a espécies florestais. Agro@mbiente On-line, 4(2), 102-109. doi: 10.18227/1982-8470ragro.v4i2.363

Gimenes, E. S., Kielse, P., Lencina, K. H., Fleig, F. D., Keathley, D. E \& Bisognin, D. A. (2015). Propagation of Cabralea canjerana by minicuttings. Journal of Horticulture and forestry, 7(1), 8-15. doi: 10.5897/ JHF2014.0367

Gomes, J. M., \& Paiva, H. N. de. (2011). Viveiros florestais: propagação sexuada. (Série didática). Viçosa: Ed. UFV.
Hartmann, H. T., Kester, D. E., Davies, F. T., \& Geneve, R. L. (2011). Plant propagation: principles and practices (8nd ed.). Nova Jersey: Prentice-Hall.

Hoagland, D. R., \& Arnon, D. I. (1950). The waterculture method for growing plants without soil. (Circ. 347). Califórnia: California Agricultural Experiment Station., Univ. of California.

Jacobs, D. F., \& Landis, T. D. (2009). Fertilization. In R. K. Dumroese, T. Luna, \& T. D. Landis (Eds.), Nursery manual for native plants: a guide for tribal nurseries (Vol. 1, pp. 15-25). Washington: Nursery management. Agriculture Handbook 730. Department of Agriculture, Forest Service.

Lorenzi, H., Souza, H. M., \& Torres, M. A. V. (2003). Árvores exóticas do Brasil: madeireiras, ornamentais e aromáticas. São Paulo: Instituto Plantarum de Estudos da Flora.

Mantovani, N., Roveda, M., Tres, L., Fortes, F. de O., \& Grando, M. F. (2017). Cultivo de canafístula (Peltophorum dubium) em minijardim clonal e propagação por miniestacas. Ciência Florestal, 27(1), 225-236. doi: 10.5902/1980509826461

Maruyama, E., Ishii, K., Saito, A., \& Ohba, K. (1993). Micropropagation of Jacaranda (Jacaranda mimosaefolia D. Don) by shoot-tip culture. Journal of the Japanese Society for Horticultural Science, 75(4), 346-349. doi: 10.11519/jjfs1953.75.4_346

Melo, L. M., Abreu, A. H. M. de, Leles, P. S. S. de, Oliveira, R. R. de, \& Silva, D. T. da. (2018). Qualidade e crescimento inicial de mudas de Mimosa caesalpiniifolia Benth. produzidas em diferentes volumes de recipientes. Ciência Florestal, 28(1), 4755. doi: 10.5902/1980509831574

Miyajima, I., Mata, D., Kobayashi, N., Facciiuto, G., Soto, S., Hagiwara, J. C.,... Escadon, A. (2004). Practical Method of Propagating Jacaranda mimosifolia by cuttings. Journal of the Japanese Society for Horticultural Science, 73(2), 137-139. doi: $10.2503 /$ jjshs. 73.137

Oliveira, T. P. F., Barroso, D. G., Lâmonica, K. R., \& Carvalho, G. C. M. W. (2016). Aplicação de AIB e tipo de miniestaca na produção de mudas de Handroanthus heptaphyllus Mattos. Ciência Florestal, 26(1), 299306. doi: 10.5902/1980509821128

Paiva, H. N., \& Gomes, J. M. (2011). Propagação vegetativa de espécies florestais. Viçosa: Ed. UFV.

Penso, G. A., Sachet, M. R., Maro, L. A. C., Patto, L. S., \& Citadin, I. (2016). Propagação de oliveira 'Koroneiki' pelo método de estaquia em diferentes 
épocas, concentrações de AIB e presença de folhas. Ceres, 63(3), 355-360. doi: 10.1590/0034$737 \mathrm{X} 201663030012$

Pimentel, N., Lencina, K. H., Pedroso, M. F., Somavilla, T. M., \& Bisognin, D. A. (2017). Morphophysiological quality of yerba mate plantlets produced by minicuttings. Semina: Ciências Agrárias, 38(6), 3515-3528. doi: 10.5433/1679-0359.2017v38n $6 \mathrm{p} 3515$

R Core Team (2017). R: A language and environment for statistical computing. Vienna, Austria: R Foundation for Statistical. Computing.

Rodrigues, M. B., Pimentel, N., Lencina, K. H., Kielse, P., \& Bisognin, D. (2017). Enraizamento de miniestacas de ipê-roxo (Handroanthus heptaphyllus Vell. Mattos). Revista Brasileira de Plantas Medicinais, 19(1), 129-137.

Silva, A. S., Reges, N. P. R., Melo, J. K., Santos, M. P., \& Sousa, C. M. (2015). Enraizamento de estacas caulinares de ixora. Ornamental Horticulture, 21(2), 201-208. doi: 10.14295/aohl.v21i2.656
Silva, R. L., Oliveira, M. L., Monte, M. A., \& Xavier, A. (2010). Propagação clonal de guanandi (Calophyllum brasiliense) por miniestaquia. Agronomiá Costarricense, 34(1), 99-104.

Taiz, L., \& Zeiger, E. (2013). Fisiologia vegetal (5a ed.). Porto Alegre: Artmed.

Tonetto, T. da S., Araujo, M. M., Muniz, M. F. B., Walker, C., \& Berghetti, A. L. P. (2015). Storage and germination of seeds of Handroanthus heptaphyllus (Mart.) Mattos. Journal of Seed Science, 37(1), 4046. doi: 10.1590/2317-1545v37n1141116

Wendling, I., Dutra, L. F., \& Grossi, F. (2006). Produção de mudas de espécies lenhosas. Colombo: EMBRAPA Florestas.

Xavier, A., Wendling, I., \& Silva, R. L. (2013). Silvicultura clonal: princípios e técnicas (2a ed.). Viçosa: Editora UFV.

Zottele, L., \& Aoyama, E. M. (2014). Morfoanatomia e enraizamento de estacas caulinares de Justicia wasshauseniana Profice (Acanthaceae). Natureza Online, 12(4), 179-184. 
